\title{
Foreign Capital Originating from the EU in Investment and Trade Activities of Polish Regions ${ }^{1}$
}

\begin{abstract}
Foreign capital inflow is viewed as a driving force of economic growth and development. To a large extent, the effects it may potentially produce depend on the location choice or, in other words, on the economic advancement of the region in question, available skills on the labour market, and the quality of infrastructure. Capital flows usually lead to the intensification of foreign trade, however, the ultimate potential outcomes of social and economic transformation within a given territory depend on the structure of trade flows. In relation to the above, this paper is motivated by the wish to grasp the pattern of foreign investment location choices (paying special attention to investors from other EU Member States) and their basic effects on the internationalisation of regions in the light of public interventions admissible in Poland. To this end, a statistical analysis of the following data will be carried out into: a) the evolution in the location pattern observed for companies with foreign capital based in Polish voivodeships (NUTS-2) in the period 2004-2017 and b) their foreign trade performance. Statistical analyses have led to the conclusion that foreign capital not only targeted better-developed regions of the country (even though their State aid offer is more limited) as the location for its investment but also companies established in these locations as a result of such investments are more strongly engaged in international trade (and are affiliates within the organisational structure of a single business entity)
\end{abstract}

\footnotetext{
^ Adam A. Ambroziak - SGH - Warsaw School of Economics, e-mail: adam.ambroziak@sgh.waw.pl, ORCID: 0000-0002-4618-8497.

1 This paper is a result of statutory research of the Collegium of World Economy, SGH- Warsaw School of Economics 2018, conducted by the Jean Monnet Chair of European Integration and co-financed with funds provided by the Ministry of Science and Higher Education.
} 
than foreign companies which chose to locate their businesses in poorer regions of the country.

Keywords: FDI, Regions, Regional Development, Foreign Trade, Poland

\section{Introduction}

Free movement of capital is one of the main freedoms of the EU Internal Market enshrined in the Treaties. Even though full liberalisation was guaranteed by the Directive adopted in $1988,{ }^{2}$ at the very outset of the European Communities, foreign direct investment (FDI) had been mutually approved without major obstacles. ${ }^{3}$ It was due to the adoption of the assumptions of economic growth theory which sees foreign capital flows as the engines of economic growth. The process is linked with the inflow of new business management ideas, new technologies, the emergence of new streams in international trade and, as a result, the development of host countries and regions. How important such stimulation is to the economy can be evidenced, inter alia, by the fact that highly developed economies rarely restrict the access of FDI to their markets. At the same time, increasingly more frequently does subject-matter literature point to the territorial dimension of government interventions in economic processes undertaken within the framework of the EU cohesion policy, ${ }^{4}$ as well as the effects of a combination of State engagement in the economy with free market investor decisions. ${ }^{5}$

Considering the above, the goal of this paper is to grasp the pattern of foreign investment location choices (paying special attention to investors from other EU Member States) and their basic effects on the internationalisation of regions through the lenses of public intervention allowable in Poland. In order to accomplish this goal, we will analyse how location choices made by companies with foreign capital at a Polish

2 Council Directive 88/361/EEC of 24 June 1988 for the implementation of Article 67 of the Treaty, OJ L 178, 8.7.1988: 5-18.

3 A.A. Ambroziak, Wplyw wprowadzenia swobodnego przeptywu kapitatu na bezpośrednie inwestycje zagraniczne w Unii Europejskiej. Bilans dwudziestolecia istnienia rynku wewnętrznego (The impact of free movement of capital on Foreign Direct Investments in the European Union. Consequences of the 20 years Internal Market of the European Union), "Studia Europejskie", No. 68(4)/2013, pp. 133-147.

4 Reshaping Economic Geography. World Development Report 2009, International Bank for Reconstruction and Development, World Bank, Washington.

5 Regional Dimension of the EU Economic Policy in Poland, ed. A.A. Ambroziak, Warsaw School of Economics Press, Warsaw 2015. 
voivodeship level (NUTS-2) evolved between 2004 and 2017 and we will also explore their international trade performance. Data covered by the study comes from Statistics Poland (Polish: Główny Urząd Statystyczny) and from the Ministry of Entrepreneurship and Technology.

At the start of an analysis of regional location and distribution of the effects of the presence of foreign capital across Polish voivodeships, we need to bear in mind the specificity of the Mazowieckie voivodeship. Warsaw, the capital city of Poland located in the Mazowieckie voivodeship, attracts big domestic and foreign companies. The proximity of central public administration offices, excellent connections with other European capitals, easy access to European-class business services, highly competent administrative staff, a big pool of top quality skilled labour, close relations with top Polish universities which maintain close contact with European and world academic centres are the main reasons, not forgetting its prestigious location, why companies register and establish their headquarters in Warsaw. Thus, many firms choose Warsaw as the location for their head offices while the real economic operations and the production of specific products take place in other parts of the country. As a result, the output, trade, and outlays originating from Warsaw and the Mazowieckie voivodeship are clearly overestimated compared to other regions of Poland whose performance is underestimated. For the above stated reason this analysis, where necessary, will refer to the Mazowieckie voivodeship without making additional comments.

The first part of this contribution presents the concept of the investment attractiveness of regions while considering the specificity of Poland followed by the discussion of the inflow and geographic location of companies with foreign capital and their foreign trade performance.

\section{Relative Investment Attractiveness of Poland's Voivodeships}

There are many theories that explore motifs as to why entrepreneurs decide to locate their investment projects outside a given country. ${ }^{6}$ On the one hand, proponents of State intervention argue that a government may play a relevant role in guiding foreign investors' decisions by offering them so-called investment incentives such as grants or tax allowances. ${ }^{7}$ On the

6 Ibidem.

7 A. Markusen, Interaction between Regional and Industrial Policies: Evidence from Four Countries, "International Regional Science Review”, No. 19/1996, pp. 4977; G.-J. Hosper, S. Beugelsdijk, Regional Cluster Policies: Learning by Comparing?, “KYKLOS”, No. 55(3)/2002, pp. 381-401; F. Barca, An Agenda for A Reformed Cohesion 
other hand, there is a vast stream of theories built around the Dunning eclectic paradigm (OLI Model - Ownership, Location and Internationalisation) ${ }^{8}$ considering, above all, endogenous factors. ${ }^{9}$ Gross Domestic Product per capita compared to the EU average seems to be a synthetic measure delineating the borders of attractiveness of Polish regions.

First, in order to eliminate any significant differences in the levels of regional development in the EU, individual Member States are expected to draw up regional aid maps for subsequent financial perspectives. ${ }^{10}$ They are used as bases for admissible government interventions taking the form of financial State aid whose intensity is inversely proportional to economic advancement of a particular region (NUTS-2): the less developed a region - the higher aid can be granted compared to the so called eligible cost. Secondly, this indicator is highly informative to potential investors: the lower the GDP per capita the lower the level of entrepreneurship, human capital engagement, and competitiveness. From one perspective, such regions offer lower production costs including the cost of labour, and public funding may mitigate the impact of these shortcomings. On the other, structural unemployment and little engagement with the labour market and business, especially when the quality of labour and infrastructure is very poor, may negatively impact entrepreneurs, especially foreign ones, in their investment decisions. Domestic companies may be driven by family sentiments, local patriotism and their being used to operating in a given social and economic environment.

Poland has been covered with a system of regional aid maps since the day of its EU accession. ${ }^{11}$ Over the last 15 years aid admissibility has evolved: at

Policy: A Place-Based Approach to Meeting European Union Challenges and Expectations, Independent Report, Prepared at the Request of the European Commissioner for Regional Policy, Danuta Hübner, European Commission, Brussels 2009.

8 J. Dunning, Toward an Eclectic Theory of International Production: Some Empirical Tests, "Journal of International Business Studies", No. 11(1)/1979, pp. 9-31; H.P. Gray, J. Duning, Towards a leory of Regional Policy, in: Regions, Globalization, and the Knowledge-Based Economy, ed. J. Duning, Oxford University Press 2002.

9 The Economics of Regional Policy, eds. H. Armstrong, J. Taylor, The International Library of Critical Writing in Economics, An Elgar Reference Collection, Cheltenham, Northampton 1999; N. Yamano, T. Ohkawara, Thee Regional Allocation of Public Investment: Efficiency of Equity, "Journal of Regional Science”, No. 40(2)/2000, pp. 205-229.

10 Guidelines on national regional aid, OJ C 74, 10.3.1998, Guidelines on National Regional Aid for 2007-2013, OJ C 54/2006, Guidelines on regional State aid for 2014-2020, OJ C 209, 23.7.2013.

11 A.A. Ambroziak, The Legal Framework for Regional State Aid in the European Union in 2014-2020 and Its Impact on the Attractiveness of Poland's Regions to Investors, in: New Cohesion Policy of the European Union in Poland. How It Will Influence the Investment Attractiveness of Regions in 2014-2020, ed. A.A. Ambroziak, Springer, Cham, 
the beginning identical aid was admissible almost across the whole country but between 2007 and 2013 investment aid was restricted to some extent in the following voivodeships: Dolnośląskie, Wielkopolskie, Śląskie, Zachodniopomorskie, and Pomorskie, and significantly reduced in the Mazowieckie voivodeship. Within the current financial perspective, maximum aid ceilings got further reduced in three voivodeships from the above list; Sląskie, Dolnośląskie, Wielkopolskie and in Warsaw (Map 1.). The Warmińskomazurskie, Podlaskie, Podkarpackie, and Lubelskie voivodeships have remained the least developed regions representing poor quality of endogenous factors but enjoying the possibility of receiving higher investment aid.

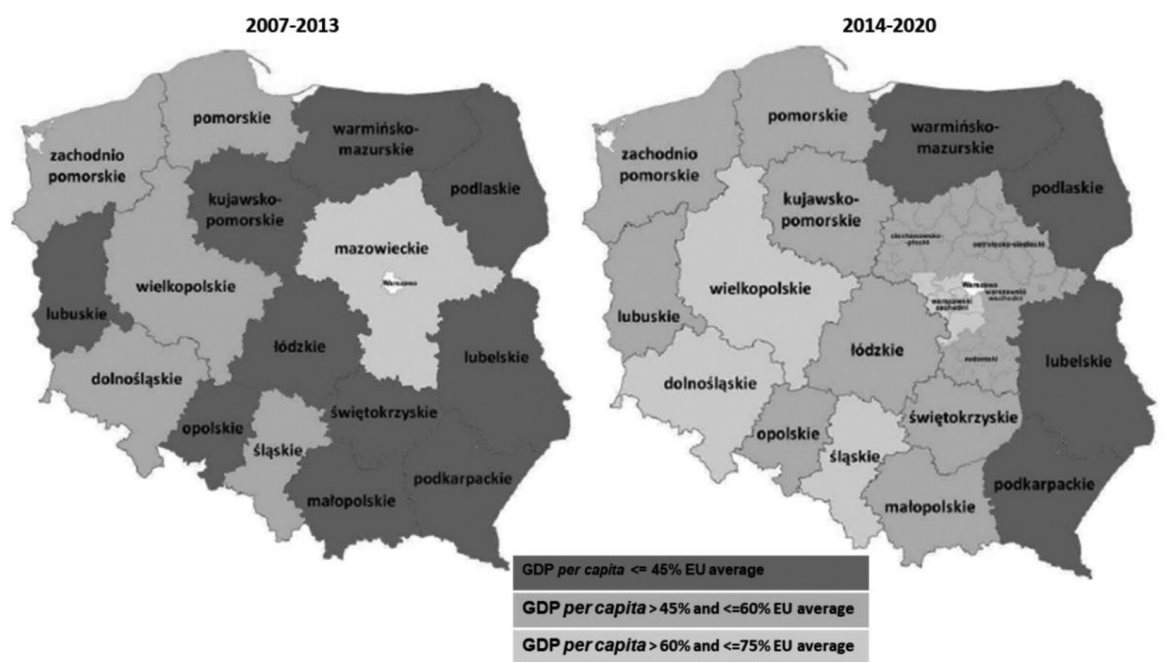

Map 1. Regional state aid map in Poland for 2007-2013 and 2014-2020.

Source: author's own compilation based on European Commission guidelines.

\section{Origin of Foreign Capital Invested in Poland}

Most foreign capital invested in Poland in 2017 originates from the EU (91.6\% of total FDI stock) with the following four Member States at the top of the list of investors: the Netherlands (20.4\%), followed by Germany (17.7\%), France (13.6\%), and Luxembourg (12.1\%) (Table 1).

\footnotetext{
Heidelberg, New York, Dordrecht, London 2014; A.A. Ambroziak, Prawne i ekonomiczne aspekty pomocy regionalnej w Polsce po akcesji do Unii Europejskiej (Legal and economic aspects of regional state aid in Poland after accession to the European Union), in: Unia Europejska w 10 lat po największym rozszerzeniu (The European Union - 10 years after the largest enlargement), eds. E. Pancer-Cybulska, E. Szostak, „Prace Naukowe Uniwersytetu Ekonomicznego we Wrocławiu”, No. 380, pp. 177-188.
} 
Table 1. FDI in companies by country of origin 2005-2017

\begin{tabular}{|l|l|l|l|l|l|l|}
\hline & & $\begin{array}{l}\text { No. of } \\
\text { compa- } \\
\text { nies }\end{array}$ & $\begin{array}{l}\text { Foreign } \\
\text { capital } \\
\text { (in mil- } \\
\text { lions of } \\
\text { PLN) }\end{array}$ & $\begin{array}{l}\text { Average } \\
\text { foreign } \\
\text { capital per } \\
\text { company }\end{array}$ & $\begin{array}{l}\text { Share } \\
\text { in total } \\
\text { foreign } \\
\text { capital } \\
(\%)\end{array}$ & $\begin{array}{l}\text { Change in } \\
\text { capital value } \\
2017 / 05\end{array}$ \\
\hline 1 & Netherlands & $2,155.0$ & $39,584.0$ & 18.4 & 20.1 & $1,693 \%$ \\
\hline 2 & Germany & $4,917.0$ & $34,955.0$ & 7.1 & 17.7 & $380 \%$ \\
\hline 3 & France & $1,092.0$ & $26,851.0$ & 24.6 & 13.6 & $1,869 \%$ \\
\hline 4 & Luxembourg & 986.0 & $23,771.0$ & 24.1 & 12.1 & $5,964 \%$ \\
\hline 5 & Sweden & 631.0 & $8,537.0$ & 13.5 & 4.3 & $979 \%$ \\
\hline 6 & United & $1,186.0$ & $8,152.0$ & 6.9 & 4.1 & $761 \%$ \\
\hline 7 & Cyngdom & $1,196.0$ & $6,802.0$ & 5.7 & 3.5 & $2,896 \%$ \\
\hline 8 & Belgium & 602.0 & $5,478.0$ & 9.1 & 2.8 & $740 \%$ \\
\hline 9 & USA & 667.0 & $5,435.0$ & 8.1 & 2.8 & $476 \%$ \\
\hline 10 & Spain & 507.0 & $5,254.0$ & 10.4 & 2.7 & $1,305 \%$ \\
\hline 11 & Italy & $1,130.0$ & $5,160.0$ & 4.6 & 2.6 & $260 \%$ \\
\hline 12 & Austria & 714.0 & $4,793.0$ & 6.7 & 2.4 & $465 \%$ \\
\hline 13 & Switzerland & 612.0 & $3,873.0$ & 6.3 & 2.0 & $694 \%$ \\
\hline 14 & Denmark & 639.0 & $3,732.0$ & 5.8 & 1.9 & $437 \%$ \\
\hline 15 & South Korea & 136.0 & $2,176.0$ & 16.0 & 1.1 & $2.522 \%$ \\
\hline 16 & Finland & 195.0 & $1,947.0$ & 10.0 & 1.0 & $1,006 \%$ \\
\hline 17 & Japan & 72.0 & $1,540.0$ & 21.4 & 0.8 & $2,069 \%$ \\
\hline 18 & Czech Republic & 588.0 & $1,194.0$ & 2.0 & 0.6 & $145 \%$ \\
\hline 19 & Norway & 320.0 & $1,110.0$ & 3.5 & 0.6 & $270 \%$ \\
\hline 20 & Hungary & 116.0 & 892.0 & 7.7 & 0.5 & $839 \%$ \\
\hline 21 & Slovakia & 159.0 & 610.0 & 3.8 & 0.3 & $570 \%$ \\
\hline 22 & China & 566.0 & 426.0 & 0.8 & 0.4 & $291 \%$ \\
\hline 23 & Canada & 88.0 & 290.0 & 3.3 & 0.2 & $128 \%$ \\
\hline 24 & Malta & 87.0 & 420.0 & 4.8 & 0.2 & $2,525 \%$ \\
\hline 25 & Portugal & 109.0 & 436.0 & 4.0 & 0.2 & $665 \%$ \\
\hline \\
\hline 6 & & & & \\
\hline
\end{tabular}

*) foreign companies employing 10 or more people by country of origin of the dominant unit in the group in 2016

Source: Działalność gospodarcza podmiotów z kapitałem zagranicznym w 2005-2017 (Economic activities of business entities with foreign capital in 2005-2017), GUS (Statistics Poland).

These four countries represented almost two thirds of total foreign capital invested in companies in Poland (63.5\%). The first non-EU country in the classification is the United States on the 9th position (2.8\%). Further places are occupied by non-EU countries, such as Switzerland, South 
Korea, Japan, Norway, and China (0.4\%). The biggest increase in the value of FDI in Poland in the period 2005-2017 was reported for the financial flows from the following EU countries: Luxembourg, Cyprus, and Malta, i.e. home countries of large investment companies, which were successfully attracted by very friendly tax arrangements. The classification looks slightly differently if we consider the average amount of foreign capital invested in a business entity. Then, France and Luxembourg (over PLN 24 mio each), Japan (21.4), the Netherlands (18.4), and Korea (21.4) are obvious leaders. Hence, these countries won their top positions in the classification having invested sizable amounts in a few Polish companies while other countries (Germany, Sweden, the United Kingdom, Belgium, and the USA) carried out relatively smaller FDI projects. It means that the majority of FDI inflowing into Poland was fragmented and there were few cases of large, individual investment projects.

\section{Foreign Capital Location Choices in Poland}

According to statistical data available for 2017, the Mazowieckie voivodeship is the principal location choice for foreign capital targeting Poland (46.5\%) followed by Wielkopolskie (12\%), Śląskie and Dolnośląskie (8.6\% each), and Małopolskie (8.1\%). The smallest share in the total stock of invested capital was reported by the weakest voivodeships economically, i.e., Podlaskie (0.3\%), Warmińsko-mazurskie (0.7\%), Lubuskie $(0.8 \%)$, and Lubelskie $(0.9 \%)$. To a certain extent, the above division is conditioned with historical aspects as well as with the existing development potential. An analysis of the changes in the value of foreign capital over the period 2004-2017 (Diagram 1) is a relevant criterion that validates the directions of location choices. The biggest increase, compared to the base year, was recorded in the Zachodniopomorskie voivodeship at the Polish-German border, representing high potential when it comes to the extension of the sea harbour to cater for energy-based raw material supplies (LNG), Lubelskie (with thriving scientific centres), Dolnośląskie, Kujawskopomorskie, and Podlaskie, in which relatively higher growth dynamics were due, above all, to a very low base value reported for 2004. Aboveaverage increases in the value of capital were also observed in the Łódzkie, Opolskie, Pomorskie, and Warmińsko-mazurskie voivodeships, however, one needs to bear in mind that in their case the per capita value of foreign capital is two or even three times lower than in the best performing voivodeships (with the exception of Mazowieckie), which shows their very poor ability to attract FDI. Świętokrzyskie was the only voivodeship which reported a decrease in the value of inflowing foreign capital while 
in Podkarpackie and Lubuskie increases in FDI value were minimal. The above changes are not reflected in the intensity of regional aid, which means that there were other factors decisive in the attractiveness of foreign capital investment.

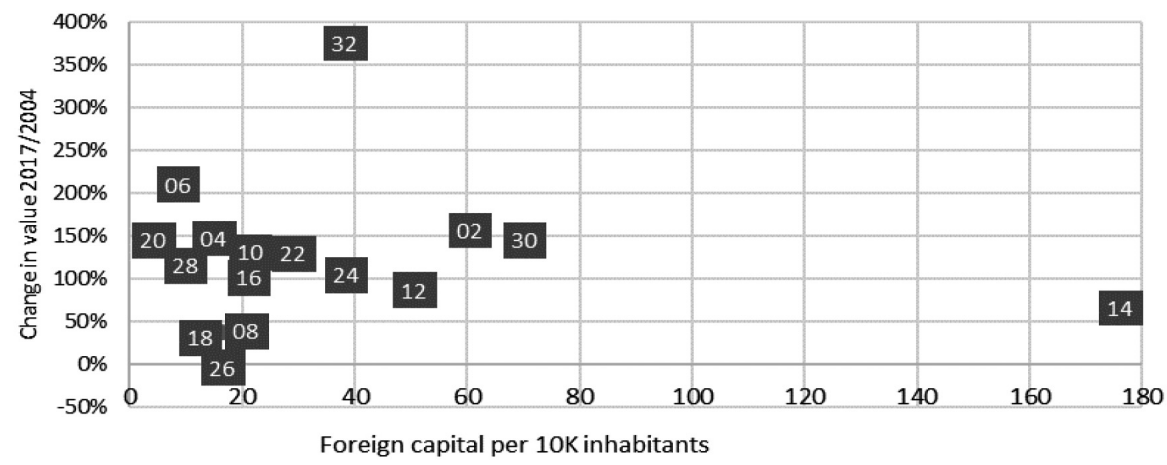

\begin{tabular}{|l|l|l|l|l|l|}
\hline no. & voivodeship & no. & voivodeship & no. & voivodeship \\
\hline 02 & Dolnośląskie & 14 & Mazowieckie & 26 & Świętokrzyskie \\
\hline 04 & Kujawsko-pomorskie & 16 & Opolskie & 28 & Warmińsko-mazurskie \\
\hline 06 & Lubelskie & 18 & Podkarpackie & 30 & Wielkopolskie \\
\hline 08 & Lubuskie & 20 & Podlaskie & 32 & Zachodniopomorskie \\
\hline 10 & Łódzkie & 22 & Pomorskie & & \\
\hline 12 & Małopolskie & 24 & Śląskie & & \\
\hline
\end{tabular}

Diagram 1. Foreign capital distribution across Polish voivodeships between 2004 and 2017 (value)

Source: GUS BDL (Statistics Poland, Local Data Base).

When analysing the value of foreign capital broken down by voivodeships and the country of origin we can note that most foreign capital originating from a given country is obviously invested in the Mazowieckie voivodeship although there are exceptions to this rule. One of them is Italian capital, which clearly favours the Śląskie voivodeship (25.1\% of FDI made by Italian capital concerning automotive factories traditionally linked with Italian investment) and, although to a smaller extent, the Danish links with Pomorskie (24.7\% of Danish capital) (Table 2).

Remarkably, for the majority of countries covered by the analysis which supplied more than $1.5 \%$ of foreign capital to Poland, Wielkopolskie (the Netherlands - 18.2\%, Germany - 23\%, Belgium, 15.6\%), Śląskie (Luxembourg $-18.5 \%$, Cyprus $-8.7 \%$, Spain - 9\%) but also Dolnośląskie (Switzerland $-10.1 \%$, Italy $-7.7 \%$, USA $-4.4 \%$ ), and Małopolskie (Luxembourg 20.7\% and the United Kingdom 12.3\%) were "second" location choices after Mazowieckie. This list should be supplemented with voivodeships 
A.A. Ambroziak, Foreign Capital Originating from the EU in Investment...

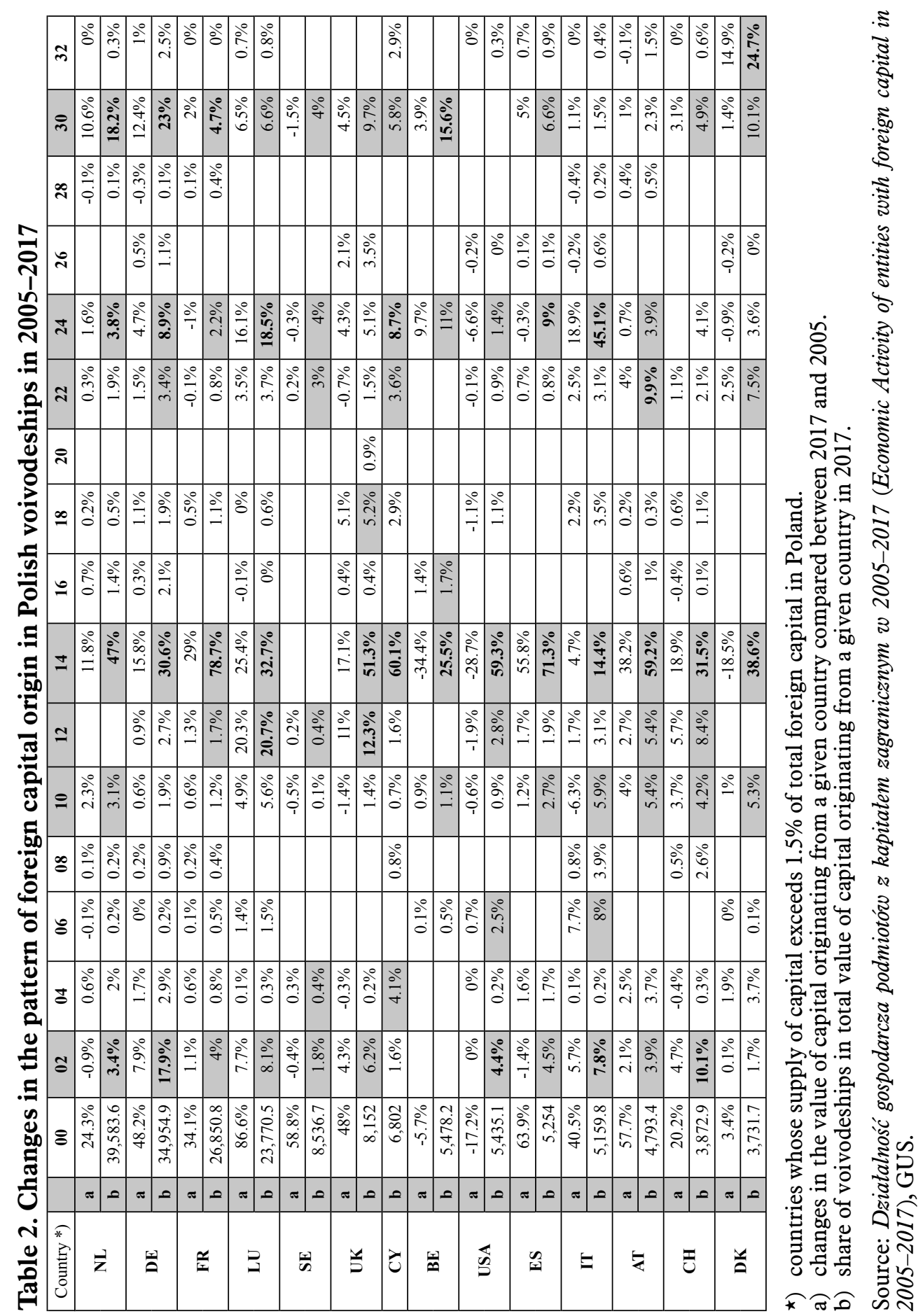


ranking usually third or fourth with respect to their share in FDI location choices: Pomorskie (Austria - 9.9\%) and Łódzkie (most of the above listed countries have several percent shares in their investment portfolio).

Thus, we may observe that the share of foreign capital originating from other countries - the biggest FDI suppliers - is the highest (over 80\%) in relatively better developed regions of Poland and the lowest in the least developed voivodeships (Warmińsko-mazurskie - 17.8\% and Podlaskie $19.0 \%$ ). This means that investors from different countries (not only from the EU because available data confirms the same tendency for capital originating from the USA and Switzerland) aim to achieve geographic concentration of their economic activities. That may be due to the fact that entrepreneurs from one and the same country have the same suppliers and customers and, to some degree, they transfer operations within the framework of clusters. The aforesaid clearly concords with Krugman's New Economic Geography theory, even though he referred to individual industries and cooperation within agglomeration. ${ }^{12}$

\section{Polish Voivodeship Performance in Foreign Trade of Companies with Foreign Capital}

FDI presence in Polish regions has its internal and external dimensions. On the one hand, trade with other countries ensures the inflow of goods that may become components of finished products and, on the other hand, exports help in expanding the output and improving the competitive position. However, the question remains at which stage of the value chain there are companies with foreign capital that pursue trade activities within the international setting. We need to know whether, in the case of imports, we are speaking about bringing components to Poland to manufacture finished goods, a solution which guarantees access to new technologies, or whether Polish affiliates of international companies are treated only as cheap manufacturers with low value added. Similarly, for exports, it is important whether companies with foreign capital offer finished goods or semi-finished products and whether they get included in the value chain.

According to data from 2017, the following voivodeships were leaders in imports and exports of foreign companies in total trade pursued by these entities: Mazowieckie, Śląskie, Dolnośląskie, and Wielkopolskie (which together account for $77.8 \%$ of total imports to Poland pursued by foreign companies and $64.9 \%$ of exports) (Tables 3 and 4). Noteworthily,

12 P. Krugman, Geography and Trade, MIT Press, Massachusetts 1991. 
these are better developed regions of Poland which, despite relatively lower intensity of investment aid, were chosen as investment locations for foreign capital by the Netherlands, Germany, Belgium, Denmark, Italy, and Luxembourg, as well as, to a lesser extent, by the USA and Switzerland. The least developed voivodeships from Eastern Poland and Świętokrzyskie reported the worst performance in trade of companies with foreign capital.

Table 3. Foreign companies imports in 2017

\begin{tabular}{|l|l|l|l|l|l|l|l|l|}
\hline & \multicolumn{1}{|c|}{$\mathrm{a}$} & \multicolumn{1}{c|}{$\mathrm{b}$} & \multicolumn{1}{c|}{$\mathrm{c}$} & $\mathrm{d}$ & $\mathrm{d}$ & $\mathrm{f}$ & $\mathrm{g}$ & \multicolumn{1}{c|}{$\mathrm{h}$} \\
\hline $\mathrm{PL}$ & $51.5 \%$ & 41.6 & $100 \%$ & $45.4 \%$ & $41 \%$ & $9.8 \%$ & $29.4 \%$ & $25.4 \%$ \\
\hline 14 & $51.2 \%$ & 37.2 & $32.5 \%$ & $19.8 \%$ & $64.3 \%$ & $13.1 \%$ & $33.1 \%$ & $34.7 \%$ \\
\hline 30 & $57.8 \%$ & 68.9 & $16.7 \%$ & $42.8 \%$ & $48.2 \%$ & $6.3 \%$ & $32.5 \%$ & $18.2 \%$ \\
\hline 24 & $54.4 \%$ & 51.9 & $13.0 \%$ & $68.4 \%$ & $17.2 \%$ & $9.5 \%$ & $30.1 \%$ & $27 \%$ \\
\hline 02 & $54.8 \%$ & 41.7 & $9.6 \%$ & $71.2 \%$ & $17.6 \%$ & $6.1 \%$ & $27.6 \%$ & $16.6 \%$ \\
\hline 12 & $46.6 \%$ & 34.1 & $6.0 \%$ & $49.9 \%$ & $36 \%$ & $9.4 \%$ & $23.6 \%$ & $20.6 \%$ \\
\hline 10 & $55.2 \%$ & 40.1 & $4.3 \%$ & $55.3 \%$ & $31.8 \%$ & $7.3 \%$ & $32.8 \%$ & $19.4 \%$ \\
\hline 22 & $51.6 \%$ & 34.1 & $4.2 \%$ & $53.8 \%$ & $35.4 \%$ & $8.6 \%$ & $31.8 \%$ & $10.4 \%$ \\
\hline 18 & $46.2 \%$ & 54.2 & $2.7 \%$ & $49.6 \%$ & $22.1 \%$ & $22.8 \%$ & $20.3 \%$ & $26.7 \%$ \\
\hline 08 & $51.8 \%$ & 40.4 & $2.3 \%$ & $79.4 \%$ & $9.5 \%$ & $7.7 \%$ & $24.0 \%$ & $40.8 \%$ \\
\hline 16 & $55.0 \%$ & 43.2 & $2.0 \%$ & $59.3 \%$ & $33.5 \%$ & $4.1 \%$ & $21.3 \%$ & $17.7 \%$ \\
\hline 04 & $51.4 \%$ & 34.1 & $1.9 \%$ & $62.4 \%$ & $26.5 \%$ & $5.7 \%$ & $23.8 \%$ & $8.8 \%$ \\
\hline 32 & $41.9 \%$ & 19.2 & $1.9 \%$ & $62.9 \%$ & $18.4 \%$ & $11.7 \%$ & $22.6 \%$ & $13.4 \%$ \\
\hline 28 & $42.6 \%$ & 51.5 & $0.9 \%$ & $57.3 \%$ & $37.7 \%$ & $2.5 \%$ & $24.1 \%$ & $67.3 \%$ \\
\hline 06 & $40.4 \%$ & 21.3 & $0.8 \%$ & $68.0 \%$ & $19.2 \%$ & $9.1 \%$ & $12.8 \%$ & $16.8 \%$ \\
\hline 26 & $51.8 \%$ & 39.7 & $0.7 \%$ & $63.4 \%$ & $23 \%$ & $8.2 \%$ & $17.6 \%$ & $16.1 \%$ \\
\hline 20 & $52.0 \%$ & 23.1 & $0.5 \%$ & $34.1 \%$ & $25.9 \%$ & $14.1 \%$ & $14.0 \%$ & $19.7 \%$ \\
\hline
\end{tabular}

a - share of importers in the total population of companies with foreign capital

$\mathrm{b}$ - average imports per company with foreign capital

c - share of voivodeships in imports of foreign companies

$\mathrm{d}$ - share of imports of raw materials and materials for production in total imports of companies with foreign capital

e - share of imports of goods for further resale in total imports of companies with foreign capital

f - share of imports of services in total imports of companies with foreign capital

$\mathrm{g}$ - share of importers from the parent company in the total population of importers with foreign capital

$\mathrm{h}$ - share of imports from parent companies in the total value of imports carried out by companies with foreign capital

Explanations of numbers, see Diagram 3.

Source: Działalność gospodarcza podmiotów z kapitatem zagranicznym w 2017 (Economic Activity of entities with foreign capital in 2017), GUS. 
We also need to look at the intensity with which companies with foreign capital engage in international trade: more than half $(51.5 \%)$ of such entities were active in imports, while almost half $(49 \%)$ in exports. The highest percentage of foreign companies involved in international trade was reported in the most developed voivodeships: Wielkopolskie $(57.8 \%$ in imports and 56.5\% in exports), Śląskie (54.4\% and 55\%), Dolnośląskie (54.8\% and 51.7\%), as well as Opolskie (55.0\% and 60.2\% respectively), and Łódzkie (55.2\% and 57\%). On the other hand, the lowest percentage of foreign companies engaged in international trade could be found in the least developed Polish voivodeships. Similar groups of voivodeships can be identified for an average value of exports and imports of companies with foreign capital. However, the group of voivodeships - leaders when it comes to the value of investment and trade of companies with foreign capital, should be extended to cover two of the least developed: Podkarpackie and Warmińsko-mazurskie. In their case, the above average value of exports and imports of companies with foreign capital results from the fact that investors based in them generated substantial outlays and trade flows. However, these are single cases, which, because of their limited scale, cannot impact the position of a voivodeship the way it happens in better developed regions.

As a rule, companies with foreign capital mainly import components for further production, processing, and assembly in Poland. From a productstructure point of view, voivodeships for which imports of raw materials and materials for production are particularly important are: Lubuskie (79.4\% of the total imports of the region), Dolnośląskie (71.2\%), Sląskie (68.4\%), but also Lubelskie (68\%). Voivodeships such as: Mazowieckie, Wielkopolskie but also Warmińsko-mazurskie, Małopolskie, and Pomorskie consider imports connected with further resale especially important. It is indicative of the domination of an intermediary rather than production operations in the activities of companies with foreign capital based in these regions. Imports of services are especially important for foreign companies based in the Podkarpackie and Podlaskie voivodeships. In other regions the share of such imports in total imports is clearly smaller. It means foreign companies based in relatively better developed regions of the country, originating predominantly from the EU, can use services available in Poland (not necessarily locally) which eliminates the need to use service providers from other countries. It is especially relevant in the face of production servitization and the growing added value offered by services. This is how Polish entrepreneurs, and service providers in particular, can get engaged in value chains. 
A.A. Ambroziak, Foreign Capital Originating from the EU in Investment...

Table 4. Exports of foreign companies in Poland in 2017

\begin{tabular}{|l|l|l|l|l|l|l|l|l|}
\hline & \multicolumn{1}{|c|}{$\mathrm{a}$} & \multicolumn{1}{c|}{$\mathrm{b}$} & \multicolumn{1}{c|}{$\mathrm{c}$} & \multicolumn{1}{c|}{$\mathrm{d}$} & \multicolumn{1}{c|}{$\mathrm{e}$} & \multicolumn{1}{c|}{$\mathrm{f}$} & $\mathrm{g}$ & $\mathrm{h}$ \\
\hline $\mathrm{PL}$ & $49.0 \%$ & 47.5 & $100 \%$ & $69.4 \%$ & $17.6 \%$ & $13.0 \%$ & $32.9 \%$ & $34.3 \%$ \\
\hline 14 & $42.0 \%$ & 33.4 & $22.1 \%$ & $44.3 \%$ & $38.7 \%$ & $16.9 \%$ & $36.0 \%$ & $30.9 \%$ \\
\hline 24 & $55.0 \%$ & 77.1 & $17.9 \%$ & $82.7 \%$ & $6.4 \%$ & $10.9 \%$ & $32.5 \%$ & $18.7 \%$ \\
\hline 30 & $56.5 \%$ & 65.1 & $14.2 \%$ & $76.9 \%$ & $9.2 \%$ & $13.9 \%$ & $35.4 \%$ & $59.2 \%$ \\
\hline 02 & $51.7 \%$ & 53.7 & $10.7 \%$ & $81.5 \%$ & $11.3 \%$ & $7.2 \%$ & $36.0 \%$ & $30.3 \%$ \\
\hline 12 & $46.9 \%$ & 36.9 & $6.0 \%$ & $62.9 \%$ & $23.6 \%$ & $13.5 \%$ & $28.3 \%$ & $34.5 \%$ \\
\hline 22 & $55.7 \%$ & 41.3 & $5.0 \%$ & $62.8 \%$ & $18.7 \%$ & $18.5 \%$ & $37.4 \%$ & $26.8 \%$ \\
\hline 10 & $57.0 \%$ & 41.6 & $4.2 \%$ & $72.2 \%$ & $16.5 \%$ & $11.3 \%$ & $36.4 \%$ & $47.1 \%$ \\
\hline 18 & $50.9 \%$ & 73.6 & $3.7 \%$ & $71.1 \%$ & $11.4 \%$ & $17.5 \%$ & $25.8 \%$ & $41.8 \%$ \\
\hline 32 & $46.3 \%$ & 36.5 & $3.7 \%$ & $75.2 \%$ & $15.6 \%$ & $9.2 \%$ & $26.3 \%$ & $39.3 \%$ \\
\hline 08 & $61.6 \%$ & 53.8 & $3.4 \%$ & $86.6 \%$ & $9.1 \%$ & $4.3 \%$ & $25.4 \%$ & $36.0 \%$ \\
\hline 04 & $56.9 \%$ & 54.6 & $3.1 \%$ & $76.8 \%$ & $7.4 \%$ & $15.8 \%$ & $28.8 \%$ & $26.2 \%$ \\
\hline 16 & $60.2 \%$ & 40.1 & $1.9 \%$ & $75.2 \%$ & $11.8 \%$ & $13.0 \%$ & $26.0 \%$ & $23.7 \%$ \\
\hline 28 & $49.0 \%$ & 66.2 & $1.3 \%$ & $87.3 \%$ & $1.7 \%$ & $11.0 \%$ & $25.0 \%$ & $77.4 \%$ \\
\hline 26 & $57.3 \%$ & 65.1 & $1.2 \%$ & $76.3 \%$ & $7.7 \%$ & $16 \%$ & $19.1 \%$ & $14.8 \%$ \\
\hline 06 & $45.1 \%$ & 26.6 & $1.0 \%$ & $81.8 \%$ & $9.7 \%$ & $8.5 \%$ & $16.7 \%$ & $25.9 \%$ \\
\hline 20 & $52.5 \%$ & 36.3 & $0.7 \%$ & $39.3 \%$ & $49.9 \%$ & $10.8 \%$ & $18.1 \%$ & $25.1 \%$ \\
\hline
\end{tabular}

a - share of entities engaged in exports in the total population of companies with foreign capital

b - average exports of companies with foreign capital

c - share of voivodeships in the exports of foreign entities

$\mathrm{d}$ - share of exports of goods in total exports of companies with foreign capital

e - share of exports of services in total exports of companies with foreign capital

$\mathrm{f}$ - share of exports of products and materials in total exports of companies with foreign capital

g - share of entities which export to their parent companies in the total population of exporters with foreign capital

$\mathrm{h}$ - share of exports to parent companies in the total value of exports carried out by companies with foreign capital

Explanations of numbers, see Diagram 3.

Source: Dziatalność gospodarcza podmiotów z kapitatem zagranicznym w 2017 (Economic Activity of entities with foreign capital in 2017), GUS.

When it comes to exports, foreign companies focused first and foremost on exporting goods $(69.4 \%)$ rather than services (17.6\%) and on offering further components (13\%). Goods are especially important in the exports of foreign companies based in voivodeships such as Warmińsko-mazurskie (87.3\%), Lubuskie (86.6\%), Lubelskie (81.6\%) but also Śląskie (82.7\%), and Dolnośląskie (81.5\%). Besides Mazowieckie, the following voivodeships are leading exporters of services: Podlaskie (49\%), Małopolskie (23.6\%), Pomorskie (18.7\%), and Łódzkie (16.5\%). When it comes to exports of components for further processing, Pomorskie (18.5\%) and Podkarpackie $(17.5 \%)$ reported a relatively higher share. 
The above classifications indicate a traditional business model of foreign companies, especially those originating from the EU, which focus on the production of goods and exporting them with a relatively small share of services or products and materials for further processing. These findings are confirmed by an analysis of trade links between foreign companies and their parent companies. Given the number of entities and the value of trade flows in most better developed voivodeships, especially those which host foreign companies intensely involved in trade activities, the share of import and export transactions with their parent companies significantly exceeded $30-40 \%$. This therefore means that a number of companies with foreign capital have become manufacturers of components or finished products for parent companies from their home countries. Less developed voivodeships are sources of finished products for final resale.

\section{Conclusions}

Generally speaking, foreign capital, in particular capital originating from richer EU Member States, views relatively better developed voivodeships, such as Dolnośląskie, Śląskie, and Wielkopolskie as the most attractive even though, paradoxically, State aid intensity allowable in these voivodeships is the lowest. There are also important historical aspects (e.g., Śląskie with its Italian FIAT factory) often significantly strengthened with the concentration of similar companies from the same industries, as well as strategic locations in transport routes (Dolnośląskie with the A4 motorway joining the region of Ślaskie with Germany and Wielkopolskie with the A2 motorway linking Poznan with Berlin come to mind). However, the mere vicinity of the border cannot guarantee an attracting of foreign capital, which can be evidenced by the relatively poorer performance of the Pomorskie and Lubuskie voivodeships at the border with Germany. Apparently, Lubuskie is a clear case showing that the A2 motorway ensures better transport connections with Wielkopolskie region rather than contributes to boosting investment intensity in the voivodeship. There are also coastal voivodeships in Poland which enjoy access to ports and can provide space for foreign capital. On the other hand, less developed regions with much higher State aid ceilings have failed to attract companies with foreign capital from the EU Member States (they accounted for only just over a dozen percent of the total value of foreign investment).

When it comes to including Polish regions in international trade flows through companies with foreign capital, an important role was again played by better developed regions which hosted companies with foreign capital originating from richer EU Member States. While imports were dominated with components for the production of finished products, ex- 
ports dealt with finished products and, much more rarely, with products subject for further processing. What is important, however, are trade patterns with parent companies: companies based in better developed regions often trade with their affiliates, which means Polish voivodeships get included in value chains. On the other hand, companies with foreign capital based in economically weaker voivodeships most often trade in finished goods. It often means components manufactured in other countries are only assembled there. Imports of services originate mainly from less developed voivodeships and are clearly smaller in better developed regions. Thus, as in the first case, specific services, including business services that ensure the highest value added are not offered by domestic companies to companies with foreign capital based in little developed regions; better developed Polish voivodeships can satisfy the needs of foreign capital.

In summary, foreign capital not only chooses to invest in better developed regions but establishes companies which are more strongly engaged in international trade than foreign companies which decided to operate in poorer regions of Poland.

\section{References}

Ambroziak A.A., Prawne i ekonomiczne aspekty pomocy regionalnej w Polsce po akcesji do Unii Europejskiej (Legal and economic aspects of regional state aid in Poland after accession to the European Union), in: Unia Europejska w 10 lat po największym rozszerzeniu (The European Union 10 years after the largest enlargement), eds. E. Pancer-Cybulska, E. Szostak, "Prace Naukowe Uniwersytetu Ekonomicznego we Wrocławiu”, No. 380/2015, s. 177-188, DOI: https://doi.org/10.15611/pn.2015.380.15.

Ambroziak A.A., The Legal Framework for Regional State Aid in the European Union in 2014-2020 and Its Impact on the Attractiveness of Poland's Regions to Investors, in: New Cohesion Policy of the European Union in Poland. How It Will Influence the Investment Attractiveness of Regions in 2014-2020, ed. A.A. Ambroziak, Springer, Cham, Heidelberg, New York, Dordrecht, London 2014, DOI: https://doi.org/10.1007/978-3319-05335-6_4.

Ambroziak A.A., Wptyw wprowadzenia swobodnego przeptywu kapitatu na bezpośrednie inwestycje zagraniczne w Unii Europejskiej. Bilans dwudziestolecia istnienia rynku wewnętrznego (The impact of free movement of capital on Foreign Direct Investments in the European Union. Consequences of the 20 years Internal Market of the European Union), "Studia Europejskie", No. 68(4)/2013, pp. 133-147. 
Barca F., An Agenda for A Reformed Cohesion Policy: A Place-Based Approach to Meeting European Union Challenges and Expectations, Independent Report, Prepared at the Request of the European Commissioner for Regional Policy, Danuta Hübner, European Commission, Brussels 2009.

Council Directive 88/361/EEC of 24 Fune 1988 for the implementation of Article 67 of the Treaty, OJ L 178, 8.7.1988: 5-18.

Dunning J., Toward an Eclectic Theory of International Production: Some Empirical Tests, "Journal of International Business Studies", No. 11(1)/1979, pp. 9-31, DOI: https://doi.org/10.1057/palgrave.jibs.8490593.

Gray H.P., Duning J., Towards a theory of Regional Policy, in: Regions, Globalization, and the Knowledge-Based Economy, ed. J. Duning, Oxford University Press 2002, DOI: https://doi.org/10.1093/0199250014.003.0017.

Guidelines on National Regional Aid for 2007-2013, OJ C 54/2006.

Guidelines on national regional aid, OJ C 74, 10.3.1998.

Guidelines on regional State aid for 2014-2020, OJ C 209, 23.7.2013.

Hosper G.-J., Beugelsdijk S., Regional Cluster Policies: Learning by Comparing?, "KYKLOS", No. 55, Vol. 33, pp. 381-401, DOI: https://doi. org/10.1111/1467-6435.00192.

Krugman P., Geography and Trade, MIT Press, Massachusetts 1991.

Markusen A., Interaction between Regional and Industrial Policies: Evidence from Four Countries "International Regional Science Review", No. 19(1-2)/ 1996, pp. 49-77, DOI: https://doi.org/10.1177/016001769601900205.

Misturai F., Rouleti C., The determinants of Foreign Direct Investment. Do statutory restrictions matter?, OECD Working Papers on International Investment 2019/01, DOI: https://doi.org/10.1787/18151957.

Regional Dimension of the EU Economic Policy in Poland, ed. A.A. Ambroziak, Warsaw School of Economics Press, Warsaw 2015.

Reshaping Economic Geography. World Development Report 2009, International Bank for Reconstruction and Development, World Bank, Washington 2009.

Taylor J., Wren C., UK Regional Policy: An Evaluation, "Regional Studies", No. 31(9)/1997, pp. 835-848, DOI: https://doi.org/10.1080/ 00343409750129959.

The Economics of Regional Policy, The International Library of Critical Writing in Economics, eds. H. Armstrong, J. Taylor, An Elgar Reference Collection, Cheltenham, Northampton 1999.

Yamano N., Ohkawara T., The Regional Allocation of Public Investment: Efficiency of Equity, "Journal of Regional Science", No. 40(2)/2000, pp. 205-229, DOI: https://doi.org/10.1111/0022-4146.00172. 